\title{
Seasonal resource conditions favor a summertime increase in North Pacific diatom-diazotroph associations
}

\author{
Christopher L. Follett ${ }^{1} \cdot$ Stephanie Dutkiewicz ${ }^{1} \cdot$ David M. Karl $^{2,3} \cdot$ Keisuke Inomura $^{1} \cdot$ Michael J. Follows $^{1}$
}

Received: 21 October 2016 / Revised: 7 October 2017 / Accepted: 24 October 2017 / Published online: 15 February 2018

(c) The Author(s) 2018. This article is published with open access

\begin{abstract}
In the North Pacific Subtropical Gyre (NPSG), an annual pulse of sinking organic carbon is observed at $4000 \mathrm{~m}$ between July and August, driven by large diatoms found in association with nitrogen fixing, heterocystous, cyanobacteria: Diatom-Diazotroph Associations (DDAs). Here we ask what drives the bloom of DDAs and present a simplified traitbased model of subtropical phototroph populations driven by observed, monthly averaged, environmental characteristics. The ratio of resource supply rates favors nitrogen fixation year round. The relative fitness of DDA traits is most competitive in early summer when the mixed layer is shallow, solar irradiance is high, and phosphorus and iron are relatively abundant. Later in the season, as light intensity drops and phosphorus is depleted, the traits of small unicellular diazotrophs become more competitive. The competitive transition happens in August, at the time when the DDA export event occurs. This seasonal dynamic is maintained when embedded in a more complex, global-scale, ecological model, and provides predictions for the extent of the North Pacific DDA bloom. The model provides a parsimonious and testable hypothesis for the stimulation of DDA blooms.
\end{abstract}

\section{Introduction}

Half of global primary production occurs in the surface ocean [1-3] where organic particles are generated and sink, moving carbon from the surface to the deep sea [4]. Once there, microbes continue to process and mediate the transfer of particles to dissolved organic carbon and carbon dioxide $[5,6]$. The storage of carbon in the deep ocean modulates atmospheric carbon dioxide on both short and geologic time scales $[7,8]$ and is thus an important part of the climate system. Oligotrophic gyres comprise $60 \%$ of earth's surface area and contribute up to half of annual carbon export to the deep sea [9]. The environmental conditions of the North

Christopher L. Follett

follett@mit.edu

1 Department of Earth, Atmospheric and Planetary Sciences, Massachusetts Institute of Technology, Cambridge, MA, USA

2 Department of Oceanography, School of Ocean and Earth Science and Technology, University of Hawai'i at Mānoa, Honolulu, HI, USA

3 Daniel K. Inouye Center for Microbial Oceanography: Research and Education, University of Hawai'i at Mānoa, Honolulu, HI, USA
Pacific Subtropical Gyre (NPSG) are well characterized by the Hawaii Ocean Time-series (HOT) project and, when compared with high latitudes, the conditions are relatively constant $[10,11]$.

In the NPSG two seemingly related events dominate the seasonal carbon cycle. First, a spatially heterogeneous build-up of large, nitrogen-fixing organisms occurs in early summer [12-14]. This is followed by a short-lived summertime export pulse (SEP) of organic carbon, which contributes $\sim 20 \%$ of the yearly total [15], with summertime export accounting for up to $60 \%$ [16]. In this article, we build a simplified ecological model that correctly predicts the summertime build-up of large, nitrogen-fixing phytoplankton when driven by the observed average environmental conditions in the NPSG. We find the changes in light, phosphate, and iron concentrations to be especially important. When this simple model is embedded in the more complicated system of a global-scale, ecological model, the predictions hold. This suggests that simple relationships between nutrients, light, and competition may hold the key toward predicting not only the timing, but the stochastic fluctuations in these blooms. Although we do not explicitly model the SEP, we find that it coincides with a seasonal change in the competitive landscape and discuss potential relationships. 


\section{Scientific background and research objectives}

The NPSG is characterized by highly stratified surface waters with low productivity and export production [10], punctuated by the SEP that reaches $4000 \mathrm{~m}[12,14,15]$. The export event is observed at Station ALOHA, a site in the NPSG [11, 15, 17], and appears to be driven by blooms of large diatoms associated with nitrogen-fixing symbionts (diatom-diazotroph associations, DDAs; see Fig. 1) [1820]. The summertime diatom bloom is evidenced by an increase in the concentration of particulate silica at Station ALOHA [21] (Fig. 2a), which peaks in July and declines in
August-the time at which the deep sediment traps record the export pulse (Fig. 2b). The regularity and timing of the export pulse led to the hypothesis that DDAs actively sink in an event tied to the solar cycle [15].

This summertime proliferation of large cells stands in contrast to the base ecological state of the system. The planktonic community in the oligotrophic surface ocean is dominated by pico-phytoplankton, notably Prochlorococcus, whose small size leads to high nutrient affinities and low subsistence concentrations of key resources [22-24]. Co-existing with this population are diverse nitrogen fixers [13, 25-27], adapted to conditions where the relative delivery rates of iron, phosphorus, and nitrogen lead
Fig. 1 Micrographs of DDAs taken near Station ALOHA, July 2015, show the major groups of DDAs present in the surface ocean. a Rhizosolenia sp. are the largest, most abundant, DDA near Station ALOHA and contain Richelia sp. symbionts inside the diatom frustule. b Chaetocerous sp. contain many symbionts attached to the outside of the frustule. c Richelia $s p$. dislodged from its host. Notice the large heterocyst with the trailing daughter cells. d Hemiaulus $s p$. also contain the symbionts on the inside. Images: C.L. Follett
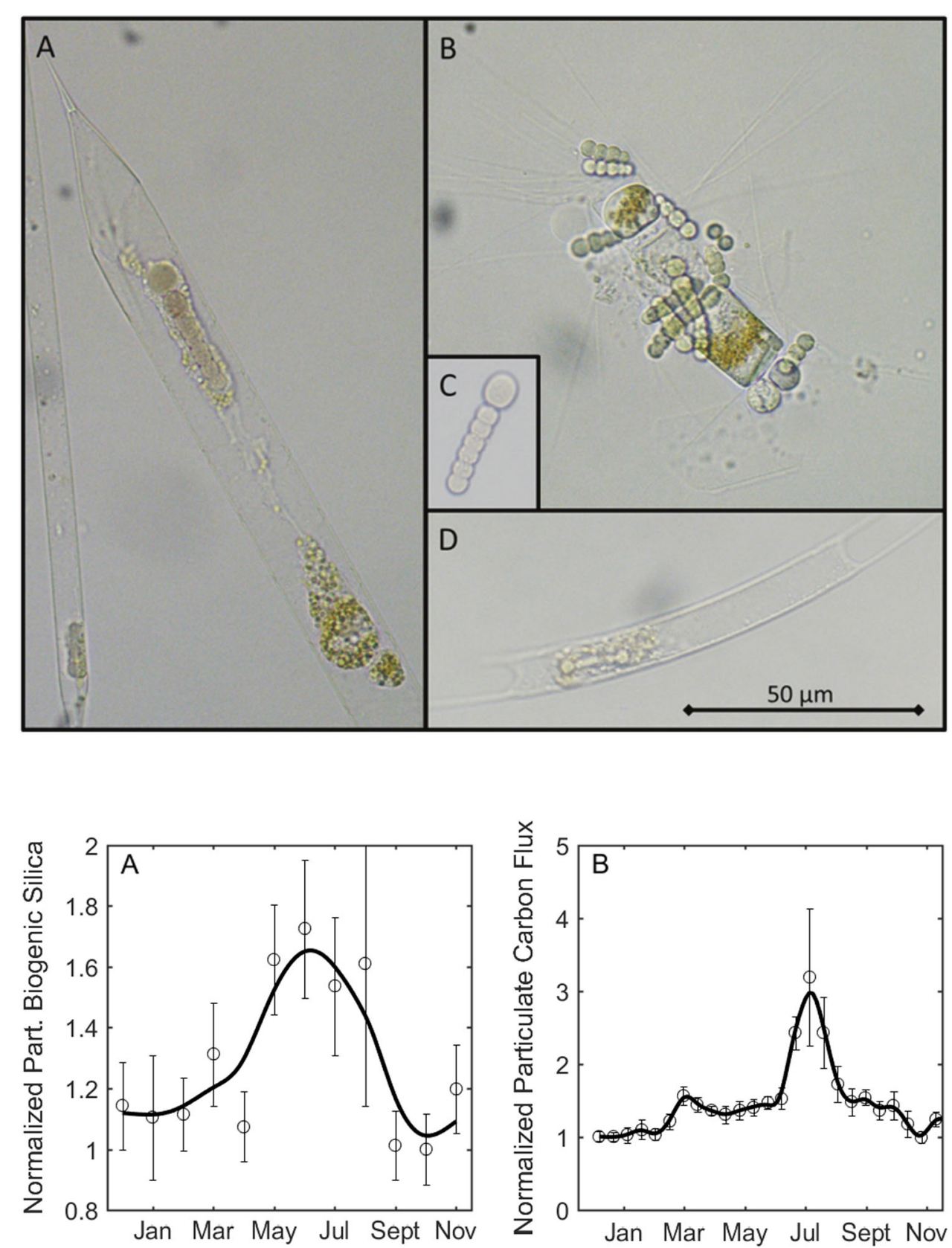

Fig. 2 Summertime DDA bloom at Station ALOHA. a Particulate biogenic silica increases in concentration in the euphotic zone during the summer months [21] because of an increase in production from DDAs. b This bloom is followed by an August pulse of particulate carbon that reaches the sea floor [97], here measured at $4000 \mathrm{~m} \mathrm{[15]}$ 
to nitrogen limitation of the most abundant primary producers but leave other resources available to sustain a nitrogen-fixing population [28]. A large area of the NPSG, including Station ALOHA, falls into this regime. A diverse array of nitrogen-fixing organisms persists at Station ALOHA, including unicellular, free-living Crocosphaera [29], colonies of Trichodesmium [30], unicellular types in symbiosis with haptophytes (UCYN-A) [25], as well as the DDA symbiosis [15, 31-34].

Several studies have focused on the generation and detection of these bloom events in the NPSG [12, 30, 3437]. Processes implicated in bloom formation include mesoscale physics [13, 37], stratification [12, 30], and a dust-borne iron source [31]. The ability of large nitrogenfixing organisms to regulate their buoyancy has been posed as a behavioral mechanism for bloom formation of large nitrogen fixers under high light, shallow mixed layer conditions $[12,14]$. As large nitrogen fixers can migrate in the water column to find nutrients, these authors suggest that DDAs and Trichodesmium sink down to access phosphorus, and return to the surface to access light [30, 38, 39]. Blooms of DDAs are spatially stochastic and unpredictable [12, 14] but seem to occur with regular seasonality [12], witnessed by the associated export pulses at Station ALOHA [15]. This conundrum led to the hypothesis that DDAs actively synchronize their sinking events to the solar cycle.

We seek to identify and model the driving forces that shape the average seasonal variations within the diazotroph populations: can we interpret and predict the seasonal succession of nitrogen fixers in the NPSG? How do large, symbiotic DDAs persist and even reach bloom densities in the face of competition from small, unicellular diazotrophs that are apparently more suited to highly oligotrophic conditions [12, 14, 15, 31-34]? Are special behaviors like active buoyancy regulation required to explain the prevalence of large nitrogen-fixing organisms in the NPSG?

We approach these questions quantitatively using a simple model that does not resolve top-down controls or behavioral adaptations. The relative growth rates of DDAs and other planktonic functional groups are calculated based on their size, taxonomic group, and environmental conditions. Size is a "master-trait", governing many important characteristics of plankton including maximum growth rate, nutrient affinities, light-harvesting characteristics, and sinking speeds. Models of marine plankton populations have exploited observed allometric relationships to structure traits and trade-offs (e.g., [40-42]), resolving a high diversity of cell size with relatively few parameters. Empirical studies (e.g., [43]) and theoretical considerations (e.g., [44]) provide the underpinnings for allometrically constrained, trait-based models. Recent efforts combine the allometric constraints with functional-type models (e.g., [45]) and embed them in three-dimensional ocean circulation and biogeochemistry models [46-48]. Here we adopt the model structure, allometric and taxonomic traits, and parameters of the ecological model of Dutkiewicz et al. [48] and introduce a new, DDA functional type. By driving this model with the monthly average ecological conditions at Station ALOHA taken monthly from 1989 to 2015, more detail in the caption of Fig. 4, we find that virtual DDAs are favored by a faster realized growth rate during summer months and lose that advantage coincident with the SEP. The relative abundance of iron and phosphorus determines which diazotroph is favored. The model DDAs are then placed in a coupled physical-biogeochemical model that resolves additional environmental and ecological complexity including top-down control by explicit grazers and feedbacks between organisms and the nutrient environment [48]: the seasonal fluctuation of DDAs predicted by the simpler model is maintained in this more realistic setting. Together, these results suggest that top-down controls or behavioral adaptations are not required to explain the seasonal cycle in diazotroph abundance. We suggest that this cycle, when combined with the local fluctuations found in the real ocean, may synchronize with, or even promote, the evolution of an active timing mechanism for sinking DDAs. This may be related to the active buoyancy controls found in these organisms [12, 14], and coincide with a change from relative iron limitation to phosphorus limitation. The quantitative details of such a model are beyond the scope of this study but should be the topic of future research.

\section{Traits and the ecological context}

The relative fitness of organisms can be partly understood, and mathematically encapsulated, in terms of maximum growth rate and subsistence resource concentration [49, 50]. From a bottom-up perspective, organisms with the highest population growth rates can out-compete others, driving them towards exclusion. In permanently nutrient starved regimes, having the lowest subsistence concentration $\left(\mathrm{R}^{*}\right)$ with respect to the limiting resource is an advantage. Empirical evidence and geometric considerations suggest that small cell size is a major factor in reducing $\mathrm{R}^{*}$, hence the dominance of the smallest prokaryotic cells in the subtropical gyres [10, 22, 51]. High maximum growth rates also reduce $\mathrm{R}^{*}[49,51,52]$. Realized growth rates are a function of environmental conditions, but maximum population growth rates have empirical and theoretical relationships to cell size. For eukaryotes, over large size ranges, smaller cells have higher maximum specific resource affinities and maximum growth rates [22, 43, 44, 53, 54]. There are also phylogenetic patterns $[43,44]$ with diatoms tending to the highest growth rates, size for size (see Fig. 3), relative to other groups [43]. Opportunistic diatoms tend to dominate many bloom situations. Diazotrophs trade off nitrogen 
Fig. 3 Phytoplankton growth rates: a The range of growth rates as a function of cell radius for some of the functional groups used in the model framework. The range is the 10-90 percent range for growth rates using monthly data from Station ALOHA. Diatom (N Replete) is the growth rate when nitrogen limitation is alleviated. With added nitrogen Diatoms out compete DDAs because they require less iron. b Nonsymbiotic diazotrophs grow slower than non-diazotrophs. Laboratory measured growth rates for Trichodesmium, Crocosphaera, DDAs, and Diatoms. Each group contains at least 5 independent measurements. Data compiled from [98-111]
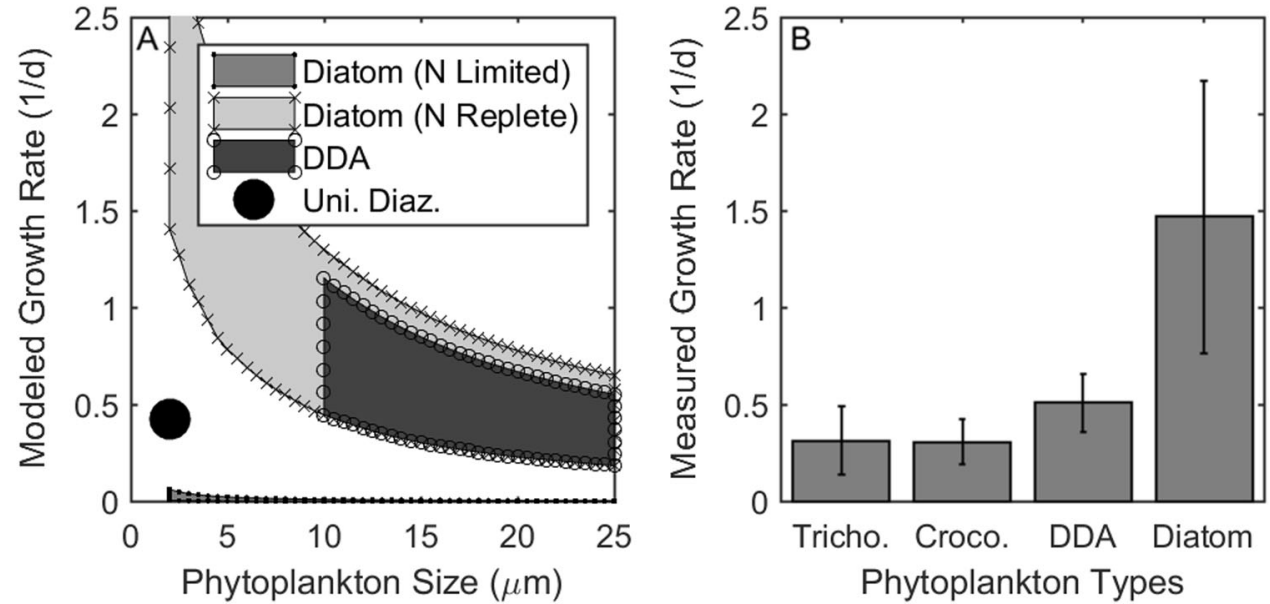

fixation against high iron demand [55] and slower growth rates (see Fig. 3); both are costs associated with the maintenance and protection of nitrogenase $[56,57]$. They are adapted to a subset of oligotrophic environments. Thus, DDAs interestingly represent a successful coalition of very different ecological strategies: a partnership between an opportunist and a gleaner with respect to nitrogen.

Trait-based models encode significant phenotypic differences in the quantitative parameterizations of growth and loss processes (see Methods). A virtual environment can be populated with a number of phenotypes and the system will self-sort according to relative fitness. Recent global ocean simulations adopt this approach, allometrically and phylogenetically (functionally) structuring key traits and tradeoffs $[47,48]$. The emergent populations in such simulations capture significant aspects of the large-scale distribution of plankton assemblages and biogeochemical fluxes. Here we take this trait-based approach to explore hypothesized controls on DDA fitness and biogeography.

First, in the Methods section, we define the mathematical framework of our population model and the parameterizations of key traits and trade-offs. In the context of a previously published ecology, [47, 48], we represent DDAs by combining the traits typically assigned to large diatoms and diazotrophs, modeling the partnership as a discrete phenotype but not resolving each partner. Then, in the results section we evaluate the seasonal variations in growth rates of DDAs in the NPSG by driving the model with observed, environmental forcing from Station ALOHA. The model reveals a clear, bottom-up driving of a summer bloom and a summer-time fitness advantage relative to unicellular diazotrophs. This advantage is lost coincident with the timing of the late summer export pulse. Finally, we include the "virtual DDA" in a global ocean ecological model to predict the regional and seasonal biogeography for DDAs in the wider NPSG.

\section{Methods: a trait-based model}

Here we describe the trait-based model of marine primary producers, $[47,48]$, introducing a representative DDA type. Then, we drive a simplified version with observed climatological monthly environmental parameters from Station ALOHA [10, 11] and local iron data [58, 59] to evaluate the fitness of DDAs relative to other phytoplankton types on a seasonal basis.

We relate the time rate of change of a phytoplankton population of type $i, N_{i}$, to first-order descriptions of growth, rate $\mu_{i}$ day $^{-1}$, and mortality, rate $m_{i}$ day $^{-1}$,

$\frac{d N_{i}}{d t}=\mu_{i} N_{i}-m_{i} N_{i}$.

For the simplified model, to be driven by observations, we will ignore loss terms and base our predictions on the relative growth rates of different phytoplankton functional types. Loss due to predation and general mortality are explicitly taken into account in the global model [48]. We will put our simulated DDA into this more complex environment in a later section.

We relate the growth rate $\left(\mu_{i}\right)$ to the local nutrient $\left(R_{j}\right.$ $(\mu \mathrm{M}))$ and light $\left(I_{0}\right)$ environment with a Liebig's Law and Monod kinetics treatment of limiting nutrients, multiplied by a light dependent factor. This is done by combining an 
equation for the light independent growth rate

$\mu_{i}^{*}=\min _{j}\left\{\frac{\mu_{\infty i} R_{j}}{\kappa_{i j}+R_{j}}\right\}$,

with a light dependent term [60, 61]. This yields

$$
\mu_{i}=\mu_{i}^{*}\left(1-e^{\frac{-I_{0} \Sigma_{\mathrm{i}} e^{-k z}}{\mu_{i}^{*}}}\right) .
$$

Here $\mu_{\infty i}$ is the maximum growth rate, dissolved inorganic resources are denoted $R_{j}$, and $\kappa_{i j}$ is a half-saturation for type $i$ with respect to resource $j$. The light dependence is a much more complicated equation. Here, $I_{0}$ is the incident photon flux at the surface; $\Sigma_{i}$ is the product of quantum yield, $\mathrm{Chl}_{\mathrm{a}}$ specific absorption spectra and Chl:C ratio; and $k$ is the light attenuation with depth $z[48,60,61]$. The light dependent factor is a concave function which saturates at a maximum value. Its maximum value is set by the nutrient condition which is why the maximum growth rate $\mu_{i}^{*}$ exists both as a multiplier and in the exponent of Eq. 3.

We assume that organisms and nutrients are well mixed within the mixed layer and evaluate the average growth rate over the mixed layer depth, depth $z_{m} \mathrm{~m}$ :

$$
\left\langle\mu_{i}\right\rangle \approx \frac{1}{z_{m}} \int_{0}^{z_{m}} \mu_{i} d z
$$

To evaluate growth rates we must quantify the time dependent environmental variables $R_{j}, I_{0}$, and $z_{m}$ and the phytoplankton traits $\mu_{i}^{*}, \kappa_{i j}$ and $\Sigma_{i}$. The HOT [10] provide almost three decades of monthly observations for $R_{j}, I_{0}$ and $z_{m}$ in the NPSG. Values of the allometry of trait parameters for various types of plankton can be obtained from compilations of empirical data [43] with theoretical interpretations [44]. In the following subsection, we explain this framework, and use previously established allometric and taxonomic patterns of parameter values [48].

\section{DDAs in a Size-Structured Trait Framework}

Empirical and theoretical studies over the last few decades have demonstrated patterns in the size of natural plankton populations [22] and the organization of key traits including maximum growth rate and nutrient affinities by size [43, 44]. These patterns provide the foundation for size-structured models of plankton populations [40, 42, 62], greatly reducing the number of imposed parameters. While cell size can account for a significant amount of phenotypic variation, there are other factors including evolutionary innovations which lead to distinct differences between functional groups of phytoplankton. For example, while there appears to be a common, size-structuring of maximum growth rate with size within the diatom and dinoflagellate groups, there is a systematic offset between them which is consistent with genomic investigations of their different metabolic strategies [63]. Within a size class, diatoms typically have much faster autotrophic maximum growth rates than dinoflagellates, reflecting their adaptation to different lifestyles and trade-offs $[43,45]$. Recent models exploit both the allometric and phylogenetic (functional group) structuring of traits [48]. Following the work of Aksnes and Egge [44], combined with experimental constraints [43], we use

$\mu_{\infty i}^{*}=a_{i} V^{b}, \quad \kappa_{i j}=a_{i} c_{i j} V^{d}$

where $V$ is the cell volume, $a_{i}$ is a functional group $(i)$ dependent constant, and constant $c_{i j}$ depends on resource $j$ and functional group. We write the constant $c_{i j}$ in terms of a reference nutrient (normally phosphorus) by defining the stoichiometric ratio $\mathbf{R}_{i j}$ of any nutrient element to the reference:

$c_{i j}=c_{i} \mathbf{R}_{i j}$.

The model is now well posed for any functional group of organisms with stoichiometry $\mathbf{R}_{i j}$ and for which constants $a_{i}$ and $c_{i}[43,48]$ are defined. A size structure is resolved within each functional group, governed by the allometric scaling parameters $b$ and $d$ which are assumed to be constant both within and across functional groups and consistent with empirical studies [43] and theoretical considerations [44].

The scaling constants $b, c_{i}$, and $d$ (Table 1) follow from the formulations of Ward et al. [46], which in turn uses

\begin{tabular}{|c|c|c|c|c|c|c|c|c|c|}
\hline & $\begin{array}{l}\text { Max. Growth } \\
\mu_{\infty}\left(\mathrm{d}^{-1}\right)\end{array}$ & $\begin{array}{l}\text { Half-Sat. N } \\
\kappa_{i 1 l}(\mu \mathrm{M})\end{array}$ & $\begin{array}{l}\text { Half-Sat. P } \\
\kappa_{i 2 l}(\mu \mathrm{M})\end{array}$ & $\begin{array}{l}\text { Half-Sat. Fe } \\
\kappa_{i 3 l}(\mu \mathrm{M})\end{array}$ & $\begin{array}{l}\text { Growth Scaling } \\
a_{i}\left(\mathrm{~d}^{-1} \mu \mathrm{m}^{-3 \mathrm{~b}}\right)\end{array}$ & $\begin{array}{l}\text { Size } \\
(\mu \mathrm{m})\end{array}$ & Ratio N/P & $\begin{array}{l}\text { Ratio } \\
\mathrm{Fe} / \mathrm{P}\end{array}$ & $\begin{array}{l}\text { Abs. } \\
\text { Cons. } \Sigma_{i}\end{array}$ \\
\hline DDA & 1.68 & 0 & 0.13 & $5 * 10^{-4}$ & 7.5 & 40 & 16 & $4 * 10^{-3}$ & 0.021 \\
\hline \multirow{2}{*}{$\begin{array}{l}\text { Unicellular } \\
\text { Diazotroph }\end{array}$} & 0.61 & 0 & $1.5^{*} 10^{-3}$ & $6 * 10^{-6}$ & 0.75 & 4 & 16 & $4 * 10^{-3}$ & 0.014 \\
\hline & \multicolumn{2}{|c|}{$c_{i}\left(\mu \mathrm{M}^{*} \mathrm{~d}^{*} \mu \mathrm{m}^{3(\mathrm{~b}-\mathrm{d})}\right)$} & $b$ & \multicolumn{2}{|c|}{ Light Attenuation $k\left(\mathrm{~m}^{-1}\right)$} & $d$ & & & \\
\hline $\begin{array}{l}\text { Universal } \\
\text { Constants }\end{array}$ & .0233 & & -.14 & 0.05 & & .23 & & & \\
\hline
\end{tabular}

Table 1 This table contains the model parameters used for both the DDA and Unicellular Diazotroph functional groups.

Parameters are taken directly from the literature [48] and calculated from Eqs. 5-6 
literature based values used in Ward et al. [47]. See Table 2 of Ward et al. [47] for the list of literature used to deduce coefficients. The values for $a_{i}$ and the stoichiometry are taken from [48]. In particular, the differing values of $a_{i}$ are determined from a compilation of maximum growth rates from Tang [54], Maranon et al. [53], Sarthou et al. [64], and Buitenhuis et al. [65]. Previous sensitivity studies (e.g., Dutkiewicz et al. 2012, [28]) explore the effects of varying the parameters, in particular the half-saturation constants and stoichiometry. These papers show that although the specific values of biomass and nutrient concentrations do change, the mechanisms and understanding supplied by the global model are robust.

Recent work has demonstrated that this combined allometric and taxonomic (functional group) approach qualitatively captures significant aspects of observed global biogeography in global simulations [47, 48]. Here we extend this framework to resolve analogs of DDAs. As with any functional group, DDAs are defined by three parameters $a_{i}, c_{i}$, and $\mathbf{R}_{i j}$. Size scaling exponents ( $b$ and $d$ ) are the same for all groups. We assume that the DDA's maximum growth rate scales with size as a diatom but that their stoichiometry (N:P:Fe ratio) is that of a diazotroph governed by their ability to fix nitrogen and the elemental cost of maintaining nitrogenase. We also assume that the DDA-analogs acquire all their nitrogen through fixation, so they have no dependence on, or uptake of, available fixed nitrogen.

The relationship of realized growth rate and effective cell size for a subset of the functional groups including DDAs in an environment like Station ALOHA is shown in Fig. 3. Growth rates decline with increasing cell size for all functional types. Due to their small size, which imparts low subsistence resource concentrations $\left(\mathrm{R}^{*}\right)$, Prochlorococcus and unicellular diazotrophs will dominate under steady-state conditions with either sufficient nitrogen (Prochlorococcus) or nitrogen-stressed conditions (unicellular diazotrophs). Diatoms and DDAs have an advantage under time-varying conditions with temporarily, relatively replete nutrient concentrations. Small diatoms have the highest growth rates when all resources are replete. When all resources but nitrogen are replete, DDAs have the highest growth rates in this framework since the non-diazotrophic picoplankton will be nitrogen-limited and unable to attain their maximum growth rate, while DDAs have the advantage of the diatom's adaptation for fast growth over their unicellular counterparts.

The functional DDA has a specific set of competitive advantages and disadvantages when compared with either diatoms or unicellular diazotrophs. When compared to other free living diatoms, DDAs are often larger and thus have lower maximum growth rates due to allometric constraints. However, they have a competitive advantage over diatoms at low ambient nitrate concentrations because they can fix their own from elemental nitrogen. DDAs out-compete unicellular diazotrophs at higher phosphorus and iron levels but are out-competed when these become limiting. From a cost-benefit perspective, the DDA has a nitrogen advantage over diatoms but a higher iron demand. Compared to unicellular diazotrophs, DDAs have a higher maximum growth rate, but also higher nutrient requirements. This trade-off is encoded in the size difference between DDAs and the unicellular diazotroph functional group. The parameter values used are shown in Table 1.

\section{Average Seasonal Conditions at Station ALOHA}

How does this ecological framework respond to observed seasonal changes in the resource environment of the NPSG? The surface of the NPSG has high incident solar radiation and low nutrient concentrations. Average monthly values for the iron concentration [58, 59], phosphorus concentration [10], surface irradiance (Photosynthetically Active Radiation (PAR)) [10, 11], and mixed layer depth [10, 11] are presented in Fig. 4. The region is strongly stratified with a mixed layer which deepens in the winter to near 100 meters and shoals to under 50 meters in the summertime.
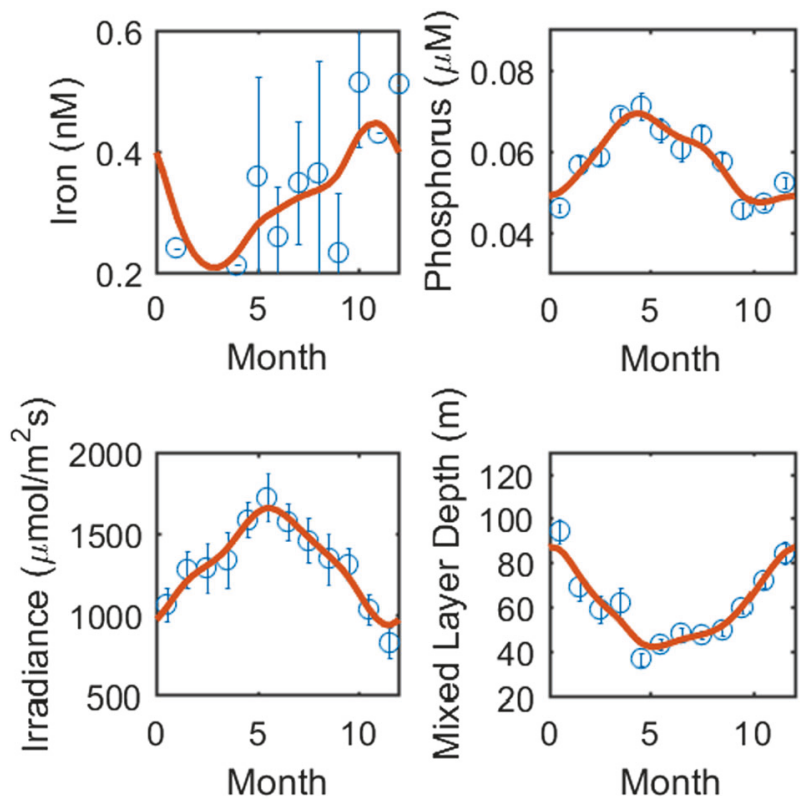

Fig. 4 Observed annual cycles of surface nutrients at Station ALOHA: Iron, Phosphorus, daily averaged surface Irradiance (photosynthetically active radiation, PAR), and Mixed Layer Depth are plotted as a function of month. Open circles represent data and the solid line is a cubic smoothing interpolant. Concentration data is averaged over the surface 0-50 meters. Irradiance (1998-2015), MLD (1989-2015), and phosphorus (1989-2015) are averages across more than a decade [10]. Iron data is collected from separate cruises in the region and is sparsely situated (1999-2013) [58, 59]. Notice the strong seasonality in all four of the data sets. Nitrate concentrations are extremely low, with an average value around $2-3 \mathrm{nM}$ in the surface ocean. It is important to note that this averaging hides substantial interannual and spatial stochasticity 
There is a seasonal fluctuation in the accessible phosphorus concentration while the dissolved inorganic nitrogen concentration is kept at trace levels by small autotrophs like Prochlorococcus. The surface ocean at Station ALOHA is characterized by excess phosphorus and enough aeolian iron deposition from above to prevent iron limitation for non-diazotrophs $[11,58]$. This nutrient state relative to the extremely low fixed nitrogen concentrations promotes the existence of nitrogen-fixing organisms which persist as large (DDAs and Trichodesmium) and small unicellular diazotrophs including Crocosphaera and UCYN-A.

Climatological monthly averages of iron, phosphorus, irradiance, and mixed layer depth were chosen as the drivers for the simplified, trait-based model. Average values were chosen both because of the relative sparsity of iron data, and to mitigate the effects of heterogeneity on short spatial and temporal scales. Using this heterogeneity to predict the spatial structure of blooms is an area for future research. Silica was not included because it is not believed to limit diatom growth in this region [66]. The dissolved organic forms of nitrogen and phosphorus, DON and DOP, were excluded from the simple formulation of the model. We argue that since inorganic nitrogen limits the growth of small autotrophs like Prochlorococcus [67] and phosphorus tends to limit diazotrophs [68] the relatively high concentrations of DON and DOP must not be readily accessible. There is clear evidence, however, that some components of the DOP are accessible on short timescales $[68,69]$. If the DON and DOP were both accessible, then the super-Redfield ratio greater than 20 in the surface NPSG should select against nitrogen fixation [28]. However, there is substantial evidence from radiocarbon suggesting that the recalcitrant deep water DOC persists in the surface ocean, and thus should be subtracted to get the accessible fraction [70]. Subtracting the concentrations of recalcitrant DON and DOP from the surface values yields a sub-Redfield N:P ratio, on average, for the accessible dissolved $\mathrm{N}$ and $\mathrm{P}$ [71]. This suggests that even if DON and DOP are both accessible, nitrogen fixation should still be selected for. Understanding the transformations of dissolved organic matter so that they can be mechanistically understood is an area of active research $[5,72,73]$. For iron, we chose an upperbound estimate for the concentration of available iron; the dissolved pool $[58,59]$. This aerosol sourced pool includes colloidal fractions [74, 75], which have been shown to be available to large nitrogen-fixing phytoplankton like DDAs and Trichodesmium [76-78]. As we have chosen an upper bound measurement, iron could certainly be more limiting than suggested in this work, but if the model parameters are correct it is unlikely to be less limiting. We want to emphasize that the seasonal iron cycle at Station ALOHA has yet to be fully characterized, and that the spatial and temporal variability is not well known $[58,59]$.

\section{Results: The seasonal cycle for DDAs at Station ALOHA}

We evaluated the seasonal variations in realized growth rate of the DDA class at Station ALOHA by driving Eq. 4 with the observed conditions. We drive the model with climatological monthly averaged surface irradiance and iron concentrations (see Fig. 4), and the individual measurements, (i.e. average surface value for a given month and year) for mixed layer depth and phosphorus concentration. The thick black bars in Fig. 5a represent the median growth rate as a fraction of that year's maximum, with the length of the bar demonstrating its sensitivity to a reasonable range of DDA size. The thin bars represent the interquartile range of the approximately 20 time points available for each month, revealing the role of inter-annual variability which we will consider in the discussion section. Peak growth rate for DDAs consistently occurs in early summer, driven by the environment. In early summer, light is maximized and an optimum is reached between falling phosphorus and increasing iron concentrations. This timing coincides with the observed increase in the average particulate silica concentrations at Station ALOHA [10, 21], and are depicted in Fig. 2. The peak reflects the time of year when iron, irradiance and mixed-layer depth conspire to provide a relatively resource-replete (though still nitrogen-limited) system. Figure $5 \mathrm{~b}$ shows the seasonality of estimated biogenic silica production, estimated by multiplying the surface particulate biogenic silica concentration by the estimated DDA growth rate. We find a sharp peak in July, consistent with the timing of the SEP. The simplified model does not resolve many complex interactions between organisms both within and across trophic levels, yet accurately predicts the maximal derivative in surface particulate biogenic silica, suggesting that the key underlying processes may have been captured. To assess the DDAs ability to compete with other diazotrophs we compare the predicted growth of DDA-analogs to that of unicellular diazotrophanalogs.

We compute the nutrient-limited growth rates of both model DDAs and unicellular diazotrophs to explore how seasonal shifts in nutrient concentration change their relative fitness. Traits are defined above (see Table 1). In Fig. 6a we show the seasonal trajectory of the average seasonal environment at Station ALOHA in phosphate-iron space. There is a hysteresis with low phosphate and iron concentrations in February and high phosphate and iron in May and June. Unicellular diazotrophs grow faster than DDAs when the limiting nutrient is low in concentration. DDA analogs have higher realized growth rates in high iron and phosphate conditions, but if either or both of these resources reaches low threshold levels then the smaller size and higher nutrient affinities of the unicellular diazotrophs gives them 


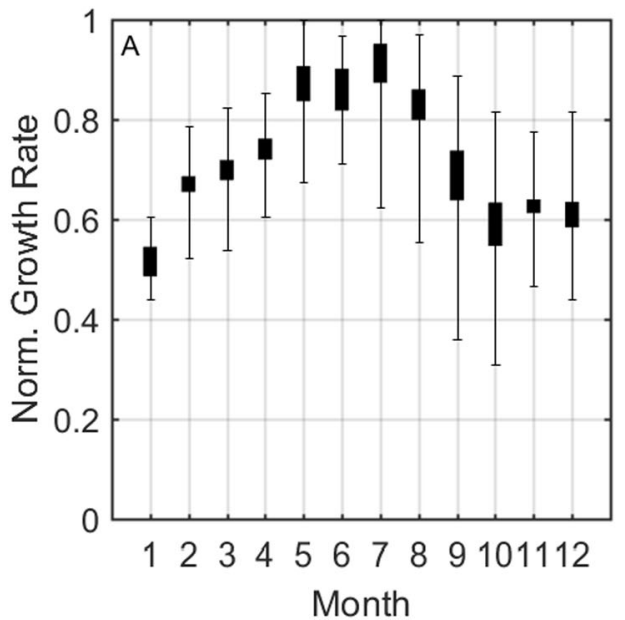

Fig. 5 Seasonal growth of DDAs at Station ALOHA: a The thick black bars are the range of monthly median growth rates normalized to each year's maximum for DDAs of different sizes ranging from $20-60 \mu \mathrm{m}$ in effective spherical diameter (ESD). The thin bars represent the full extent of the interquartile ranges over nearly 20 sampling years for a given month and the range is due to fluctuating environmental conditions. Modeled DDAs have peak realized growth rates in early summer when iron, phosphorus, and light are high and the mixed layer

the growth rate advantage. We have quantified the relative realized growth rates and indicate the regimes under which DDA or unicellular diazotroph analogs have highest growth rate in Fig. 6a. The black line separates the region where unicellular diazotrophs have a higher growth rate (left and bottom) and where DDAs have a higher growth rate (top and right). The gray shading at the boundary reveals the sensitivity to the assumed size of the DDAs.

Consistent with the resource limitation hypothesis, the model predicts that Unicellular Diazotrophs have a higher growth rate than DDAs when iron and phosphate concentrations are low, beginning in the fall. Stratification in the summer coincides with higher iron and phosphorus concentrations which make it ideal for DDAs to persist. The transition point where free nutrient concentrations select for smaller diazotrophs occurs between July and August, consistent with the timing of the seasonal export pulse at Station ALOHA [15].

\section{A seasonal cycle of DDAs in a Global ocean model}

Our simple nutrient competition framework for interpreting the seasonal stimulation of DDAs lacks many other factors which may be significant for fitness, including the two-way interaction between organisms and nutrient fields. To place this simple model in a broader context, we implement the parameterization in a biogeochemical-ecosystem model, embedded in the MIT general circulation model (MITgcm) [48]. The ocean model is based on the ECCO configuration of the MITgcm [79-81] at one-degree horizontal resolution.

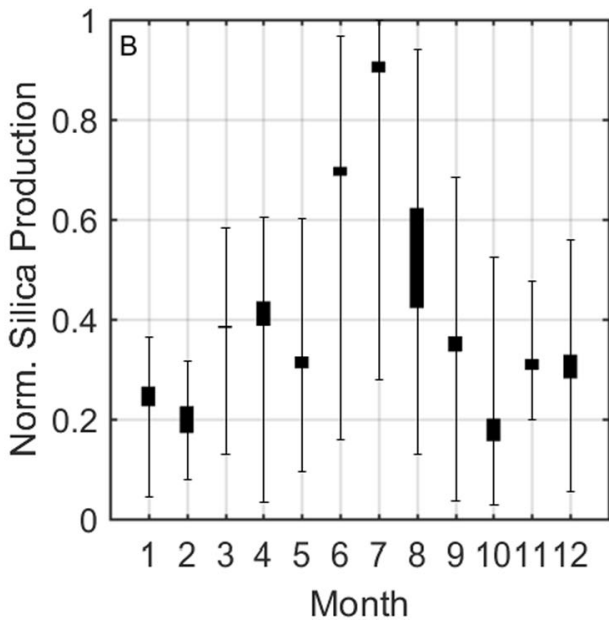

is shallow. This maximal growth rate coincides with the increase in particulate silica in Fig. 2. b Multiplying the growth rate by the particulate biogenic silica concentration allows us to estimate biogenic silica production. Bars are calculated the same way as for a. Notice the sharp peak occurring in July, just prior to the SEP. For both plots, the peak value occurs between May and August approximately 80 percent of the time

It resolves both the organic and inorganic forms of carbon, phosphorus, nitrogen, and iron. Silica and oxygen are also present. Nine phytoplankton types are resolved along with two grazers. These represent a range of functional groups including analogs of diatoms, coccolithophores, Prochlorococcus, Trichodesmium, and unicellular diazotrophs [48]. The traits of each of the groups are imposed according to cell size and functional group membership as discussed briefly above and in detail by $[47,48]$. Here, we resolve an additional DDA group, using the trait description developed and applied above. We extrapolate to a prediction of their biogeography at the basin and global scale. Here we illustrate the prediction for DDAs in the North Pacific, relevant for this particular study. DDA analogs bloom throughout large areas of the model's North Central Pacific in July, consistent with the timing of the observed blooms.

We show the predicted, North Pacific biogeography of DDAs in Fig. 7. Consistent with the observations and the idealized model, the simulations consistently predict DDAs to be more prevalent in the spring and summer, with a peak in biomass occurring during July. While diatoms dominate in the northern part of the Pacific, we find DDAs flourishing to the south of the region of major seasonal diatom blooms, where nitrogen limits diatom growth. In this nitrogen limited region, the model predicts a band of enhanced DDA concentration which extends eastward from Japan across the Pacific to the north of the Hawaiian Islands. This is broadly consistent with published observations of DDAs across the oligotrophic Pacific [15, 82], including notable abundances in the western region near Japan [83]. The presence of these 


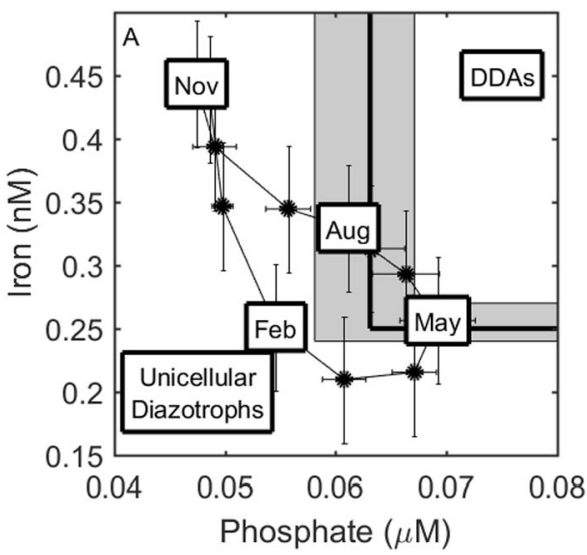

Fig. 6 DDA Seasonality: a This plot shows regions in nutrient space where either DDAs or Unicellular Diazotrophs should out-compete one another based on nutrient limited growth. Nitrate is $.0025 \mu \mathrm{M}$ but does not factor into the relative competition of modeled diazotrophs $(\kappa=0$ for nitrogen). Black circles are monthly averages interpolated from the spline fits in Fig. 4. Phosphate errors are the standard error on the mean from the HOT data set (data can be found at http://hahana.soest.hawaii. edu/hot/hot-dogs/). Iron error bars are approximately the analytic errors for the measurement [58]. The observed statistical errors are larger than the seasonal cycle because the system is very under-sampled (see Fig. 4). The thick black line is where growth rates of model DDAs

virtual DDA blooms in the ocean simulations is encouraging because the model resolves feedbacks between organisms and environment, explicit interactions with a population of grazers, as well as explicit transport by ocean circulation that were absent in the idealized model driven by imposed nutrient concentrations. In other words, the inferred mechanism of the simpler model is robust in a much more complex and realistic setting.

Significantly, the simulated DDA blooms occur in model regions where the concentrations of iron and phosphate are consistent with those measured at Station ALOHA (see Fig. 7). However, the simulation does not extend the bloom further to the southeast because the simulated iron concentration is significantly lower than is observed, decreasing the viable range for DDAs in the model relative to observed occurrences. More accurately modeling the iron cycle would potentially rectify this issue. This is an area of active research [84] and our simulation points to the need for a better understanding and modeling of both iron sources and processing. We illustrate the sensitivity of the simulated range of DDAs to the iron concentration with the thick dashed line in Fig. 7, which shows the predicted extent of the DDA bloom area if iron limitation is relieved. This wider range is more plausible, and predicts local DDA enhancement at Station ALOHA.

The ocean simulations provide confidence that some of the key simplifications of the idealized model do not critically affect the qualitative dynamics. They also provide predictions of biogeography which highlight some critical

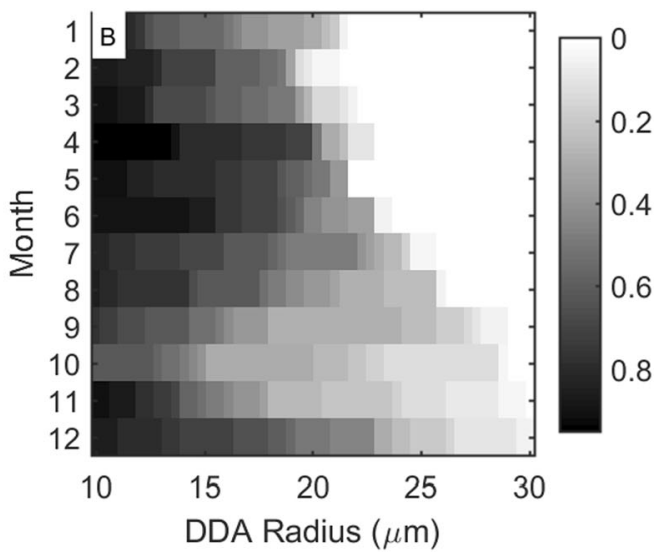

(diameter of $40 \mu \mathrm{m}$ ) and unicellular diazotrophs are equal. The gray region shows the sensitivity to $\pm 2 \mu \mathrm{m}$ in diameter for the model DDA. DDAs have a higher growth rate in the upper right region and unicellular diazotrophs have a higher growth rate in the lower left region. b This plot shows the percentage of the time our model predicts DDAs grow faster than unicellular diazotrophs in a given month out of approximately 20 sample years. The color bar represents the fraction of the time DDAs have a higher growth rate than unicellular diazotrophs in the simple model. This uses all available data. Notice the competitive advantage in December which occurs approximately half the time for DDA sizes near 20 microns

issues with the ecological and biogeochemical models which could be improved through a concerted effort to improve parameterizations of key processes and an extended and systematic observed biogeography.

\section{Discussion}

We present the hypothesis, and models to support it, that seasonal fluctuations of the nutrient environment in the NPSG are sufficient to drive the observed seasonality in the population of DDAs. We took an ecological model governed by allometric and taxonomic patterns in the traits of phytoplankton types and extended it to resolve DDAs by combining key traits of diatoms and diazotrophs. When this model is driven by observed environmental conditions from Station ALOHA, the DDA-analogs follow the broad seasonal cycle observed in the NPSG [15]. This seasonality also emerged in more complex ocean simulations which also resolve ecosystem-nutrient feedbacks, increased phytoplankton diversity, explicit grazing and dispersal. This supports the hypothesis that DDA seasonal dynamics are driven by light and nutrients rather than fluctuations in predator distribution or consumption rates.

However, there are numerous simplifying assumptions made in our model which we discuss in the following sections. In particular, while the model provides a framework for understanding the seasonal increase and decrease in DDA abundance, it has no mechanism to generate the 

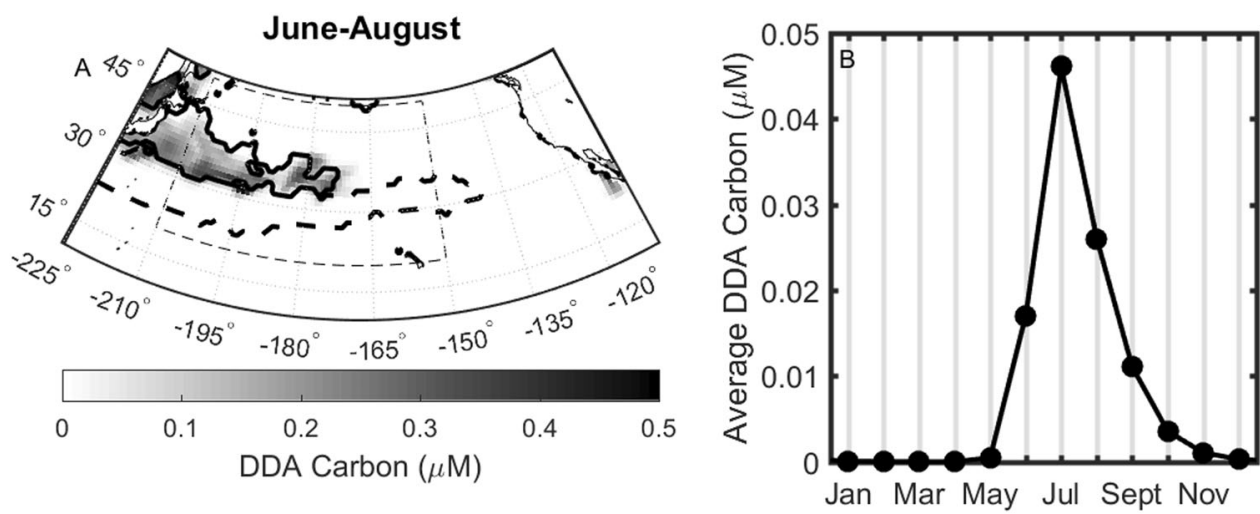

Fig. 7 DDA Competition in Global Model: Simulated DDA populations fluctuate in the NCP consistent with the observed export pulse. a Maps show simulated DDA biomass in the surface ocean during the summer. The thick black boundary shows regions where surface iron and phosphate concentrations are consistent with those found at Station ALOHA. The simulated range of DDAs includes regions of known blooms in the western North Pacific but, in this model configuration, does not extend as far east as observations near the Hawaiian Islands

sharp timing of the SEP. This can be seen in Fig. 7 where, rather than a rapid loss, the virtual DDA population declines over several months. We also discuss the role of interannual variability and speculate on both buoyancy regulation and aggregation as mechanisms connecting competition changes to the SEP. Finally, we provide predictions of the model which can be compared with in-situ observations and experimental results.

\section{What is the effect of inter-annual variability?}

It is important to remember the complexity which was averaged over in order to make our predictions. DDAs live in a turbulent, Lagrangian world and see a fluctuating environment where the variance can be large, even if the average is steady. For example, phosphorus values taken from the NPSG region north of Hawaii during the COOKBOOK cruise in April 2003, ( $<30$ degrees $\mathrm{N},<50$ meters), have no trend with latitude and range from $10-140 \mathrm{nM}$ in concentration ( 9 samples, average $80 \pm 3 \mathrm{nM}$ ) [85]. This is consistent with the data from the rest of the HOT dataset for April from 1989-2015 (77 samples, average $67 \pm 3 \mathrm{nM}$ ). $30 \mathrm{nM}$ is of similar magnitude as the climatological seasonal fluctuation which we are suggesting drives the process. A greater understanding of the local spatial/temporal variability at Station ALOHA, and an increasing temporal record of dissolved iron concentrations would allow us to further test this mechanism with year to year variability in phosphorus, iron, and the magnitude of the SEP.

Despite these caveats, we have explicitly shown the potential effects of inter-annual variability in Figs. 5 and 6 b. The whiskers in Fig. 5 are the interquartile range and show

the large inter-annual variability. However, the peak growth rate still occurs between May and August 80 percent of the time. The peak in estimated biogenic silica occurs between June and August 80 percent of the time. Thus, the seasonal fluctuation in growth appears quite robust. The seasonal competitive transitions are more sensitive, as can be seen in Fig. 6b. In addition to the summertime advantage, taking into account the inter-annual variability suggests that DDAs might also have a competitive window half the time during December. We hope that a better understanding of the spatial and high frequency temporal variation will let us use models like this to understand the strength, and rare absence of the SEP.

\section{Are complicating organisms and interactions important?}

The mechanism and model invoked to explain the summertime increases in DDAs ignore many processes and interactions which are relevant in this system. This is one reason why we do not attempt to predict the magnitude of the summertime DDA pulse. Although the nutrient mechanism presented here may very well induce DDAs, interactions with other organisms may control the bloom's final size. We invoke a simple form of interaction, competition with unicellular diazotrophs, to show how decreasing nutrient levels could lead to exclusion but we ignore the sometimes critical species, Trichodesmium.

One could rightly use the same general arguments presented here to argue that Trichodesmium should bloom during the summer, and this is indeed when it is maximally present $[12,14]$. Trichodesmium was not resolved in the idealized model here because the key traits and parameters 
which define its ecology are still unclear to us. Unlike DDAs or unicellular diazotrophs, Trichodesmium exists in many colonial size ranges precluding a simple parameterization of its growth rate. Trichodesmium appears to have special defense mechanisms against predation [86], although it is susceptible to viral lysis [87]. It grows extremely slowly [88], yet seems to persist because almost nothing eats it. It exists outside the normal growth vs. size continuum. Understanding the processes which dominate the inter-functional group competition between DDAs and Trichodesmium is an area for further research. However, slow growing, large, predator-free diazotrophs (our current best approximation of Trichodesmium) are resolved in the global model, and do not appear to inhibit the seasonality of model DDAs.

\section{Why are DDAs so large?}

By using the observed, large, size of DDAs we were able to predict an organism with growth characteristics consistent with observations yet we provide no mechanistic reasons for DDAs being so large. Under the size-rate paradigm used in this manuscript, we would expect that DDAs are as small as possible. One satisfactory argument is that the diatoms are large to match the growth rates of the symbiont, and diazotrophs are often characterized by relatively low growth rates in the laboratory (see Fig. 3b). The models we present suggest that both size and functional group determine growth rate. Symbiotic consortia must have the same growth rate on average or one of the partners will grow faster than the other, potentially eliminating the partnership. If growth and size are coupled, then the diatom may simply be large enough so that it grows slowly enough to accommodate its host. This works because diatoms typically have faster maximum growth rates than unicellular diazotrophs, but maximum growth rate decreases as cells get larger [43]. Additionally, if buoyancy is relevant to the problem, buoyancy effects are greatly enhanced with size [89].

\section{Is there a role for buoyancy regulation or aggregation in the SEP?}

Evidence exists for the vertical migration of non-symbiotic versions of the Rhizosolenia diatom [90-92] in order to obtain fixed nitrogen and large nitrogen fixers may use a similar strategy to attain phosphorus [12, 14, 30, 38]. The average conditions at Station ALOHA when combined with our model suggest that DDAs are limited seasonally by different nutrients relative to unicellular diazotrophs. DDAs are limited by phosphorus in the fall-winter and iron in the spring-summer (Fig. 6). These nutrients have very different profiles and sources, with iron being most prevalent in the very surface and phosphorus most accessible below the photic zone. If buoyancy regulation is used to harvest nutrients, different strategies would be required depending on whether phosphorus or iron were limiting. During summertime DDAs would be expected to float close to the surface in pursuit of iron, and complete a vertical migration for phosphorus the rest of the year. The transition in life strategies would coincide with the SEP, yet a mechanistic connection between the two is unclear.

The active aggregation and sinking of DDAs timed to the solar cycle, potentially as part of their reproductive phase, is consistent with our results [15]. We suggest that the proposed solar trigger occurs near a time when DDAs lose their competitive advantage. This decrease in fitness causes a decrease in the total DDA population size in the global model. Initiating the sexual phase at this time would be beneficial, as sexual reproduction in diatoms leads to sinking and a decrease in the total population [93-95]. Thus, sexual reproduction allows for the maintenance of genetic diversity without additional mortality.

\section{Testable predictions of the model}

Our model suggests that the seasonal succession of unicellular diazotrophs and DDAs is driven by the fluctuating iron and phosphate concentrations which may be observable in both the composition and growth characteristics of large nitrogen fixers in the NPSG. This succession is driven by fluctuating nutrient concentrations and may be testable through systematic nutrient amendment experiments in the surface. We predict a seasonal shift between iron and phosphate limitation in the large size class at Station ALOHA. Additionally, buoyancy driven mechanisms should drive changes in the elemental stoichiometry of DDAs across the seasons. We predict that the average $\mathrm{N}: \mathrm{P}$ ratio of the DDA size class should drop after the SEP if phosphorus collection becomes the dominant mechanism. If nitrogen fixation is augmented by nitrogen harvesting, the nitrogen isotopic composition of the large nitrogen fixing community would also change seasonally [15].

\section{Conclusion}

Nitrogen fixation supports new production in the oligotrophic surface waters of the Pacific gyres which must be coupled with export [96]. When coupled with the ecology of DDAs, this export is concentrated into a pulse, the SEP, which transports carbon into the abyssal ocean [15]. We combined the extensive data for surface nutrients at Station ALOHA with a size-structured model for the plankton population including DDAs to suggest that DDAs should bloom in early summer, consistent with particulate silica measurements. We find that model DDAs are out-competed 
by small unicellular diazotrophs later in the summer, consistent with the timing of the SEP [15], though not providing an explanation for its rapidity. Sexual reproduction, buoyancy regulation, and the solar cycle could all play a role in the sharp timing of the SEP [15]. As we continue to find ways to measure and understand the flux of nutrients in the world's ocean we must continue to remember organisms like DDAs which are small in population, but have a disproportionate effect on nutrient flux and carbon storage in the deep sea.

Funding Funding for this work was provided by the Simons Foundation (Simons Collaboration on Ocean Processes and Ecology, Award 329108 (M.J.F. and D.M.K.)), NSF (OCE-1434007 to S.D.), the Gordon and Betty Moore Foundation (GBMF \#3778 to M.J.F. and GBMF \#3794 to D.M.K.), and the Japapn Student Service Organization (K.I.).

\section{Compliance with ethical standards}

Conflict of interest The authors declare that they have no conflict of interest.

Open Access This article is licensed under a Creative Commons Attribution-NonCommercial-ShareAlike 4.0 International License, which permits any non-commercial use, sharing, adaptation, distribution and reproduction in any medium or format, as long as you give appropriate credit to the original author(s) and the source, provide a link to the Creative Commons license, and indicate if changes were made. If you remix, transform, or build upon this article or a part thereof, you must distribute your contributions under the same license as the original. The images or other third party material in this article are included in the article's Creative Commons license, unless indicated otherwise in a credit line to the material. If material is not included in the article's Creative Commons license and your intended use is not permitted by statutory regulation or exceeds the permitted use, you will need to obtain permission directly from the copyright holder. To view a copy of this license, visit http://creativecommons. org/licenses/by-nc-sa/4.0/.

\section{References}

1. Falkowski PG, Barber RT, Smetacek V. Biogeochemical controls and feedbacks on ocean primary production. Science. 1998;281:200-6.

2. Field CB, Behrenfeld MJ, Randerson JT, Falkowski P. Primary production of the biosphere: Integrating terrestrial and oceanic components. Science. 1998;281:237-40.

3. Longhurst A, Sathyendranath S, Platt T, Caverhill C. An estimate of global primary production in the ocean from satellite radiometer data. J Plankton Res. 1995;17:1245-71.

4. Buesseler KO, Lamborg CH, Boyd PW, Lam PJ, Trull TW, Bidigare RR, et al. Revisiting carbon flux through the ocean's twilight zone. Science. 2007;316:567-70.

5. Follett CL, Repeta DJ, Rothman DH, Xu L, Santinelli C. Hidden cycle of dissolved organic carbon in the deep ocean. Proc Natl Acad Sci USA. 2014;111:16706-11.

6. Smith DC, Simon M, Alldredge AL, Azam F. Intense hydrolytic enzyme activity on marine aggregates and implications for rapid particle dissolution. Nature. 1992;359:139-42.
7. Rothman DH, Hayes JM, Summons RE. Dynamics of the Neoproterozoic carbon cycle. Proc Natl Acad Sci USA. 2003;100:8124-9.

8. Volk T, Hoffert MI. Ocean carbon pumps: Analysis of relative strengths and efficiencies in ocean-driven atmospheric $\mathrm{CO}_{2}$ changes. In: Sundquist ET, Broecker WS, (eds). The Carbon Cycle and Atmospheric CO2: Natural Variations Archean to Present. Washington DC: American Geophysical Union Geophysical Monograph Series; 1985; p. 99-110.

9. Emerson S, Quay P, Karl D, Winn C, Tupas L, Landry M. Experimental determination of the organic carbon flux from open-ocean surface waters. Nature. 1997;389:951-4.

10. Karl DM, Church MJ. Microbial oceanography and the Hawaii Ocean Time-series programme. Nat Rev Microbiol. 2014;12:699-713.

11. Karl DM, Lukas R. The Hawaii Ocean Time-series (HOT) program: background, rationale and field implementation. Deep Sea Res Part II: Top Stud Oceanogr. 1996;43:129-56.

12. White AE, Spitz YH, Letelier RM. What factors are driving summer phytoplankton blooms in the North Pacific Subtropical Gyre? J Geophys Res. 2007;112:C12006. https://doi.org/10. 1029/2007JC004129.

13. Church MJ, Mahaffey C, Letelier RM, Lukas R, Zehr JP, Karl DM. Physical forcing of nitrogen fixation and diazotroph community structure in the North Pacific Subtropical Gyre. Global Biogeochemical Cycles. 2009; 23:G2020.

14. Dore JE, Letelier RM, Church MJ, Lukas R, Karl DM. Summer phytoplankton blooms in the oligotrophic North Pacific Subtropical Gyre: Historical perspective and recent observations. Progress Oceanogr. 2008;76:2-38.

15. Karl DM, Church MJ, Dore JE, Letelier RM, Mahaffey C. Predictable and efficient carbon sequestration in the North Pacific Ocean supported by symbiotic nitrogen fixation. Proc Natl Acad Sci USA. 2012;109:1842-9.

16. Quay P, Stutsman J. Surface layer carbon budget for the subtropical N. Pacific: $\delta^{13} \mathrm{C}$ constraints at Station ALOHA. Deep Sea Res Part I: Oceanogr Res Pap. 2003;50:1045-61.

17. Scharek R, Tupas LM, Karl DM. Diatom fluxes to the deep sea in the oligotrophic North Pacific Gyre at Station ALOHA. Mar Ecol Prog Ser. 1999;182:55-67.

18. Foster RA, Zehr JP. Characterization of diatom-cyanobacteria symbioses on the basis of nifH, hetR and 16S rRNA sequences. Environ Microbiol. 2006;8:1913-25.

19. Venrick E. The distribution and significance of Richelia intracellularis Schmidt in the North Pacific Central Gyre. Limnol Oceanogr. 1974;19:437-45.

20. Villareal TA. Marine nitrogen-fixing diatom-cyanobacteria symbioses. In: Carpenter, EJ and Capone, DG (eds), Marine pelagic cyanobacteria: Trichodesmium and other diazotrophs. Netherlands: Springer; 1992. pp. 163-75.

21. Brzezinski MA, Krause JW, Church MJ, Karl DM, Li B, Jones JL, et al. The annual silica cycle of the North Pacific Subtropical Gyre. Deep Sea Res Part I: Oceanogr Res Pap. 2011;58:988-1001.

22. Chisholm SW. Phytoplankton size. In: Falkowski, PG and Woodhead, AD (eds), Primary Productivity and Biogeochemical Cycles in the Sea. Boston, MA, USA: Springer; 1992. pp. 213-37.

23. Chisholm SW, Frankel SL, Goericke R, Olson RJ, Palenik B, Waterbury JB, et al. Prochlorococcus marinus nov. gen. nov. sp.: an oxyphototrophic marine prokaryote containing divinyl chlorophyll a and b. Arch Microbiol. 1992;157:297-300.

24. Verdy A, Follows M, Flierl G. Optimal phytoplankton cell size in an allometric model. Mar Ecol Prog Ser. 2009;379:1-12. 
25. Zehr JP, Waterbury JB, Turner PJ, Montoya JP, Omoregie E, Steward GF, et al. Unicellular cyanobacteria fix $\mathrm{N}_{2}$ in the Subtropical North Pacific Ocean. Nature. 2001;412:635-8.

26. Church MJ, Short CM, Jenkins BD, Karl DM, Zehr JP. Temporal patterns of nitrogenase gene (nifH) expression in the oligotrophic North Pacific Ocean. Appl Environ Microbiol. 2005;71:5362-70.

27. Karl D, Letelier R, Tupas L, Dore J, Christian J, Hebel D. The role of nitrogen fixation in biogeochemical cycling in the subtropical North Pacific Ocean. Nature. 1997;388:533-8.

28. Ward BA, Dutkiewicz S, Moore CM, Follows MJ. Iron, phosphorus, and nitrogen supply ratios define the biogeography of nitrogen fixation. Limnol Oceanogr. 2013;58:2059-75.

29. Webb EA, Ehrenreich IM, Brown SL, Valois FW, Waterbury JB. Phenotypic and genotypic characterization of multiple strains of the diazotrophic cyanobacterium, Crocosphaera watsonii, isolated from the open ocean. Environ Microbiol. 2009;11:338-48.

30. Karl DM, Letelier R, Hebel DV, Bird DF, Winn CD (1992), Trichodesmium blooms and new nitrogen in the North Pacific Gyre. In: Carpenter, EJ and Capone, DG (eds), Marine pelagic cyanobacteria: Trichodesmium and other diazotrophs. Netherlands: Springer; pp. 219-37.

31. Wilson C, Villareal TA, Brzezinski MA, Krause JW, Shcherbina AY. Chlorophyll bloom development and the subtropical front in the North Pacific. J Geophys Res. 2013;118:1473-88.

32. Hashihama F, Kanda J, Maeda Y, Ogawa H, Furuya K. Selective depressions of surface silicic acid within cyclonic mesoscale eddies in the oligotrophic western North Pacific. Deep Sea Res Part I: Oceanogr Res Pap. 2014;90:115-24.

33. Villareal TA, Adornato L, Wilson C, Schoenbaechler CA. Summer blooms of diatom-diazotroph assemblages and surface chlorophyll in the North Pacific Gyre: a disconnect. J Geophys Res. 2011;116:C03001

34. Villareal TA, Brown CG, Brzezinski MA, Krause JW, Wilson C. Summer diatom blooms in the North Pacific Subtropical Gyre: 2008-9. PLoS ONE. 2012;7:e33109.

35. Wilson, C. Late summer chlorophyll blooms in the oligotrophic North Pacific Subtropical Gyre. Geophys Res Lett. 2003;30 (18):1942.

36. Brzezinski MA, Villareal TA, Lipschultz F. Silica production and the contribution of diatoms to new and primary production in the Central North Pacific. Mar Ecol Prog Ser. 1998;167:89-104.

37. Guidi, L, Calil, PH, Duhamel, S, Björkman, KM, Doney, SC, Jackson, GA et al. Does eddy-eddy interaction control surface phytoplankton distribution and carbon export in the North Pacific Subtropical Gyre? J Geophys Res Biogeosci. 2012;117:G02024.

38. White AE, Spitz YH, Letelier RM. Modeling carbohydrate ballasting by Trichodesmium spp. Mar Ecol Prog Ser. 2006;323:35-45.

39. Villareal TA. Positive buoyancy in the oceanic diatom Rhizosolenia debyana H. Peragallo. Deep Sea Res Part A Oceanogr Res Pap. 1988;35:1037-45.

40. Laws EA. The importance of respiration losses in controlling the size distribution of marine phytoplankton. Ecology. 1975;56:419-26.

41. Armstrong RA. Stable model structures for representing biogeochemical diversity and size spectra in plankton communities. J Plankton Res. 1999;21:445-64.

42. Poulin FJ, Franks PJ. Size-structured planktonic ecosystems: Constraints, controls and assembly instructions. J Plankton Res. 2010;32(8):1121-30.

43. Litchman E, Klausmeier CA, Schofield OM, Falkowski PG. The role of functional traits and trade-offs in structuring phytoplankton communities: scaling from cellular to ecosystem level. Ecol Lett. 2007;10:1170-81.
44. Aksnes D, Egge J. A theoretical model for nutrient uptake in phytoplankton. Mar Ecol Prog Ser. 1991;70:65-72.

45. Irwin AJ, Finkel ZV, Schofield OM, Falkowski PG. Scaling-up from nutrient physiology to the size-structure of phytoplankton communities. J Plankton Res. 2006;28:459-71.

46. Ward BA, Dutkiewicz S, Follows MJ, Modelling spatial and temporal patterns in size-structured marine plankton communities: top-down and bottom-up controls. J Plankton Res. 2014;36:31-47. https://doi.org/10.1093/plankt/fbt097.

47. Ward BA, Dutkiewicz S, Jahn O, Follows M. A size-structured food-web model for the global ocean. Limnol Oceanogr. 2012;57:1877-91.

48. Dutkiewicz S, Hickman A, Jahn O, Gregg W, Mouw C, Follows M. Capturing optically important constituents and properties in a marine biogeochemical and ecosystem model. Biogeosci Discuss. 2015;12:2607-95.

49. Tilman D. Resources: a graphical-mechanistic approach to competition and predation. Am Natural. 1980;116(3):362-93.

50. Tilman, D. The resource-ratio hypothesis of plant succession. Am Natural. 1985;125(6):827-52.

51. Dutkiewicz S, Follows MJ, Bragg JG. Modeling the coupling of ocean ecology and biogeochemistry. Global Biogeochem Cycles. 2009;23:GB4017.

52. Stewart FM, Levin BR. Partitioning of resources and the outcome of interspecific competition: a model and some general considerations. Am Natural. 1973;107(954):171-98.

53. Marañon E, Cermeño P, López-Sandoval DC, Rodríguez-Ramos $\mathrm{T}$, Sobrino C, Huete-Ortega M, et al. Unimodal size scaling of phytoplankton growth and the size dependence of nutrient uptake and use. Ecology Lett. 2013;16:371-9.

54. Tang EP. The allometry of algal growth rates. J Plankton Res. 1995; 17:1325-35.

55. Howard JB, Rees DC. Structural basis of biological nitrogen fixation. Chem Rev. 1996;96:2965-82.

56. Falkowski PG. Evolution of the nitrogen cycle and its influence on the biological sequestration of $\mathrm{CO}_{2}$ in the ocean. Nature. 1997;387:272-5.

57. Kustka A, Sañudo-Wilhelmy S, Carpenter EJ, Capone DG, Raven JA. A revised estimate of the iron use efficiency of nitrogen fixation, with special reference to the marine cyanobacterium Trichodesmium spp. (cyanophyta). J Phycol. 2003;39:12-25

58. Boyle EA, Bergquist BA, Kayser RA, Mahowald N. Iron, manganese, and lead at Hawaii Ocean Time-series Station ALOHA: Temporal variability and an intermediate water hydrothermal plume. Geochim Cosmochim Acta. 2005;69:933-52.

59. Fitzsimmons JN, Hayes CT, Al-Subiai SN, Zhang R, Morton PL, Weisend RE, Ascani F, Boyle EA. Daily to decadal variability of size-fractionated iron and iron-binding ligands at the Hawaii Ocean Time-series Station ALOHA. Geochim Cosmochim Acta. 2015;171:303-24.

60. Geider RJ, MacIntyre HL, Kana TM. A dynamic model of photoadaptation in phytoplankton. Limnol Oceanogr. 1996;41:1-15.

61. Geider RJ, MacIntyre HL, Kana TM. A dynamic regulatory model of phytoplanktonic acclimation to light, nutrients, and temperature. Limnol Oceanogr. 1998;43:679-94.

62. Moloney CL, Field JG. General allometric equations for rates of nutrient uptake, ingestion, and respiration in plankton organisms. Limnol Oceanogr. 1989;34:1290-9.

63. Alexander H, Rouco M, Haley ST, Wilson ST, Karl DM, Dyhrman ST. Functional group-specific traits drive phytoplankton dynamics in the oligotrophic ocean. Proc Natl Acad Sci USA. 2015;112:E5972-E5979. 
64. Sarthou G, Timmermans KR, Blain S, Tréguer P. Growth physiology and fate of diatoms in the ocean: a review. J Sea Res. 2005;53:25-42.

65. Buitenhuis E, Pangerc T, Franklin D, Le Quere C, Malin G. Growth rates of six Coccolithophorid strains as a function of temperature. Limnol Oceanogr. 2008;53:1181-5.

66. Krause JW, Brzezinski MA, Villareal TA, Wilson C. Increased kinetic efficiency for silicic acid uptake as a driver of summer diatom blooms in the North Pacific Subtropical Gyre. Limnol Oceanogr. 2012;57:1084-98.

67. Van Mooy BA, Devol AH. Assessing nutrient limitation of Prochlorococcus in the North Pacific Subtropical Gyre by using an RNA capture method. Limnol Oceanogr. 2008;53:78-88.

68. Watkins-Brandt KS, Letelier RM, Spitz YH, Church MJ, Böttjer $\mathrm{D}$, White AE. Addition of inorganic or organic phosphorus enhances nitrogen and carbon fixation in the oligotrophic North Pacific. Mar Ecol Prog Ser. 2011;432:17-29.

69. Björkman K, Karl DM. Bioavailability of dissolved organic phosphorus in the euphotic zone at Station ALOHA, North Pacific Subtropical Gyre. Limnol Oceanogr. 2003;48:1049-57.

70. Druffel ERM, Williams PM. Radiocarbon in dissolved organic matter in the central North Pacific Ocean. Nature. 1987;330 (6145):246-248.

71. Karl DM, Björkman KM, Dore JE, Fujieki L, Hebel DV, Houlihan T, et al. Ecological nitrogen-to-phosphorus stoichiometry at station ALOHA. Deep Sea Res Part II: Top Stud Oceanogr. 2001;48:1529-66.

72. Karl DM, Björkman K. Dynamics of DOP. Biogeochemistry of marine dissolved organic matter. (2002). Dynamics of DOP. In: Hansell DA, Carlson CA (eds). Biogeochemistry of Marine Dissolved Organic Matter. London: Academic; pp. 249-366.

73. Aluwihare LI, Repeta DJ, Pantoja S, Johnson CG. Two chemically distinct pools of organic nitrogen accumulate in the ocean. Science. 2005;308:1007-10.

74. Wu J, Boyle E, Sunda W, Wen L-S. Soluble and colloidal iron in the oligotrophic North Atlantic and North Pacific. Science. 2001;293:847-9.

75. Aguilar-Islas AM, Wu J, Rember R, Johansen AM, Shank LM. Dissolution of aerosol-derived iron in seawater: leach solution chemistry, aerosol type, and colloidal iron fraction. Mar Chem. 2010;120:25-33.

76. Chappell PD, Moffett JW, Hynes AM, Webb EA. Molecular evidence of iron limitation and availability in the global diazotroph Trichodesmium. ISME J. 2012;6:1728-39.

77. Chen M, Dei RC, Wang W-X, Guo L. Marine diatom uptake of iron bound with natural colloids of different origins. Mar Chem. 2003;81:177-89.

78. Wang W-X, Dei RC. Bioavailability of iron complexed with organic colloids to the cyanobacteria Synechococcus and Trichodesmium. Aquat Microb Ecol. 2003;33:247-59.

79. Wunsch C, Heimbach P. Practical global oceanic state estimation. Phys D. 2007;230:197-208.

80. Marshall J, Adcroft A, Hill C, Perelman L, Heisey C. A finitevolume, incompressible Navier Stokes model for studies of the ocean on parallel computers. J Geophys Res. 1997a;102:5753-66.

81. Marshall J, Hill C, Perelman L, Adcroft A. Hydrostatic, quasihydrostatic, and nonhydrostatic ocean modeling. J Geophys Res. 1997b;102:5733-52.

82. Luo Y, Doney SC, Anderson LA, Benavides M, Berman-Frank I, Bode A, et al. Database of diazotrophs in global ocean: Abundance, biomass and nitrogen fixation rates. Earth Syst Sci Data. 2012;4:47-73. https://doi.org/10.5194/essd-4-47-2012. https:// doi.org/10.1594/PANGAEA.774851.
83. Gómez F, Furuya K, Takeda S. Distribution of the cyanobacterium Richelia intracellularis as an epiphyte of the diatom Chaetoceros compressus in the western Pacific Ocean. J Plankton Res. 2005;27:323-30.

84. Tagliabue A, Aumont O, DeAth R, Dunne JP, Dutkiewicz S, Galbraith E, et al. How well do global ocean biogeochemistry models simulate dissolved iron distributions? Glob Biogeochem Cycles. 2015;30:149-74.

85. Church MJ, Björkman KM, Karl DM, Saito MA, Zehr JP. Regional distributions of nitrogen-fixing bacteria in the Pacific Ocean. Limnol Oceanogr. 2008;53:63-77.

86. Hawser S, O'neil J, Roman M, Codd G. Toxicity of blooms of the cyanobacterium Trichodesmium to zooplankton. J Appl Phycol. 1992;4:79-86.

87. Hewson I, Govil SR, Capone DG, Carpenter EJ, Fuhrman JA. Evidence of Trichodesmium viral lysis and potential significance for biogeochemical cycling in the oligotrophic ocean. Aquat Microb Ecol. 2004;36:1-8.

88. Capone DG, Zehr JP, Paerl HW, Bergman B, Carpenter EJ. Trichodesmium, a globally significant marine cyanobacterium. Science. 1997;276:1221-9.

89. Moore JK, Villareal TA. Size-ascent rate relationships in positively buoyant marine diatoms. Limnol Oceanogr. 1996;41:1514-20.

90. Villareal TA, Pilskaln C, Brzezinski M, Lipschultz F, Dennett M, Gardner GB. Upward transport of oceanic nitrate by migrating diatom mats. Nature. 1999;397:423-5.

91. Villareal TA, Woods S, Moore JK, Culver-Rymsza K. Vertical migration of Rhizosolenia mats and their significance to $\mathrm{NO}_{3}{ }^{-}$ fluxes in the Central North Pacific Gyre. J Plankton Res. 1996;18:1103-21.

92. Villareal TA, Altabet MA, Culver-Rymsza K. Nitrogen transport by vertically migrating diatom mats in the North Pacific Ocean. Nature. 1993;363:709-12.

93. Crawford RM. The role of sex in the sedimentation of a marine diatom bloom. Limnol Oceanogr. 1995;40:200-4.

94. Edlund MB, Stoermer EF (1997). Ecological, evolutionary, and systematic significance of diatom life histories. J Phycol 33, 897-918.

95. Waite A, Harrison P. Role of sinking and ascent during sexual reproduction in the marine diatom Ditylum-brightwellii. Mar Ecol Prog Ser. 1992;87:113-22.

96. Böttjer D, Dore JE, Karl DM, Letelier RM, Mahaffey C, Wilson ST, et al. Temporal variability of nitrogen fixation and particulate nitrogen export at Station ALOHA. Limnol Oceanogr. 2017;62:200-16.

97. Smith K, Baldwin R, Karl D, Boetius A. Benthic community responses to pulses in pelagic food supply: North Pacific Subtropical Gyre. Deep Sea Res Part I: Oceanogr Res Pap. 2002;49:971-90.

98. Admiraal W. Influence of light and temperature on the growth rate of estuarine benthic diatoms in culture. Mar Biol. 1976;39:1-9.

99. Agawin NS, Duarte CM, Agusti S. Growth and abundance of Synechococcus $s p$. in a Mediterranean bay: Seasonality and relationship with temperature. Mar Ecol Prog Ser. 1998; 170:45-53

100. Donk E, Kilham SS. Temperature effects on silicon-and phosphorus-limited growth and competitive interactions among three diatoms. J Phycol. 1990;26:40-50.

101. Agawin NS, Duarte CM, Agust S. Response of Mediterranean Synechococcus growth and loss rates to experimental nutrient inputs. Mar Ecol Prog Ser. 2000;206:97-106.

102. Eppley RW. Temperature and phytoplankton growth in the sea. Fish Bull. 1972;70:1063-85. 
103. Fu F-X, Mulholland MR, Garcia NS, Beck A, Bernhardt PW, Warner $\mathrm{ME}$, et al. Interactions between changing $\mathrm{PCO}_{2}, \mathrm{~N}_{2}$ fixation, and $\mathrm{Fe}$ limitation in the marine unicellular cyanobacterium Crocosphaera. Limnol Oceanogr. 2008;53:2472.

104. Goebel NL, Edwards CA, Carter BJ, Achilles KM, Zehr JP. Growth and carbon content of three different-sized diazotrophic cyanobacteria observed in the subtropical North Pacific. J Phycol. 2008;44:1212-20.

105. Großkopf T, LaRoche J. Direct and indirect costs of dinitrogen fixation in Crocosphaera watsonii WH8501 and possible implications for the nitrogen cycle. Front Microbiol. 2012;3:236.

106. Holl CM, Montoya JP. Diazotrophic growth of the marine cyanobacterium Trichodesmium IMS101 in continuous culture: Effects of growth rate on $\mathrm{N}_{2}$-fixation rate, biomass, and C: $\mathrm{N}$ : $\mathrm{P}$ stoichiometry. J Phycol. 2008;44:929-37.

107. Hutchins D, Fu F-X, Zhang Y, Warner M, Feng Y, Portune K, et al. $\mathrm{CO}_{2}$ control of Trichodesmium $\mathrm{N}_{2}$ fixation, photosynthesis, growth rates, and elemental ratios: Implications for past, present, and future ocean biogeochemistry. Limnol Oceanogr. 2007;52:1293-304.

108. Liu H, Campbell L, Landry MR, Nolla HA, Brown SL, Constantinou J. Prochlorococcus and Synechococcus growth rates and contributions to production in the Arabian Sea during the 1995 Southwest and Northeast Monsoons. Deep Sea Res Part II: Top Stud Oceanogr. 1998;45:2327-52.

109. Mann EL, Chisholm SW. Iron limits the cell division rate of Prochlorococcus in the Eastern Equatorial Pacific. Limnol Oceanogr. 2000;45:1067-76.

110. Moore LR, Chisholm SW. Photophysiology of the marine cyanobacterium Prochlorococcus: Ecotypic differences among cultured isolates. Limnol Oceanogr. 1999;44:628-38.

111. Pyle AE. Light dependant growth and nitrogen fixation rates in the Hemiaulus haukii and Hemiaulus membranaceus diatomdiazotroph associations. Austin USA: MS, University of Texas; 2011. 